\title{
Hippocrates and cholesteatoma
}

\author{
Albert Mudry ${ }^{1}$ \\ Received: 22 March 2020 / Accepted: 1 April 2020 / Published online: 9 April 2020 \\ c) Springer-Verlag GmbH Germany, part of Springer Nature 2020
}

\section{Dear Editor,}

I read "The First Description of Cholesteatoma by Hippocrate" [1] with great interest. Sadly I remain unconvinced by the authors' conclusion that the subject case is "a complicated cholesteatoma with facial palsy and neuro-meningitis manifestation." Interpretation of texts from the original Hippocratic Corpus is notoriously difficult, and the attribution of modern diagnoses is always fraught with pitfalls. The interpretation of this case provides a good example of this: the diagnosis here is uncertain and lacks any really convincing evidence or logical argument.

The extract about the ear discharge must be taken in context. Notwithstanding the difficult English from the Harvard edition of the Corpus, we are told of "discharge, fistular sore and foul odor." What does the Classical scholar mean by "fistular $(\sigma v \rho i \gamma \gamma \tilde{\omega} \delta \varepsilon \zeta)$ sore"? All that is known for certain is that the lad had a long-standing ear infection, discharge and a foetid smell. In two other translations $[2,3]$ the term fistula is also used and in neither case is the site specified. Can we assume irrebuttably that it is post-aural?

Neither can we be sure that a seventh nerve palsy is absolutely certain. There is no mention of any asymmetry or lateralisation; and remember, one wonderful talent of Hippocrates is to paint us a complete and beautifully described clinical picture. We hear that "His mouth was slack, the jaws and lips always moving as though he wanted to say something." I need a lot more convincing that this is how the usually eloquent Father of Medicine would describe a facial palsy.

I am not sure about the nystagmus either. Clearly, nystagmus as such was not recognised during Hippocrates lifetime,

This comment refers to the article available online at https://doi. org/10.1007/s00405-020-05899-8.

Albert Mudry

amudry@stanford.edu

1 Department of Otolaryngology, Head and Neck Surgery, Stanford University School of Medicine, 801 Welch Road, Stanford, CA 94305-5739, USA but by the same token, it must in certain cases have existed. However, I need more evidence than "much moving of the eyes and glancing about", a "bloodshot" right eye and a swollen upper eyelid to convince me of nystagmus. As I see it, there is no proof of either a right facial palsy or a labyrinthitis in this text. The diagnosis is most probably an acute fatal episode of a chronic suppurating ear infection, which was a regularly encountered occurrence before the antibiotic era. The authors have surpassed themselves however with their suggestion that the bacteriological culprit was Streptococcus pyogenes.

There appears to be absolutely no clinical evidence for cholesteatoma in this Hippocratic text. This is in comparison to the clear case cited by Duverney in 1683 [4], which remains unchallenged as the first precisely recorded case.

Two much less important criticisms are: that I harbour strong doubts that the tympanic membrane was recorded on medical papyri in ancient Egypt; and finally that Politzer was the first person to describe secretory otitis media (although he was certainly the first to illustrate it) [5].

As always, may I make a plea for authors of historical papers to cite primary original references rather than secondary ones.

Thank you for your kind consideration of this letter.

\section{References}

1. Benmoussa N, Fabre C, Deo S, Prêtre C, Charlier P (2020) The first description of cholesteatoma by Hippocrate. Eur Arch Otorhinolaryngol. https://doi.org/10.1007/s00405-020-05899-8

2. Littré E (1846) Oeuvres complètes d'Hippocrate, V edn. Baillière, Paris, p 373 (avec fistule et écoulement de mauvaise odeur)

3. Hippocrate JJ (2003) Epidémies V et VII, IV edn. Belles Lettres, Paris, pp 53-55 (accompagné de flux, fistules et de mauvaise odeur)

4. Duverney GJ (1683) Traité de l'organe de l'ouïe. Michallet, Paris, p 183

5. Politzer A (1867) Diagnose und Therapie der Ansammlung seröser Flüssigkeit in der Trommelhöhle. Wien Med Wochenschr 17:244-247

Publisher's Note Springer Nature remains neutral with regard to jurisdictional claims in published maps and institutional affiliations. 